\title{
COPING WITH THE MEANINGLESSNESS OF POLITICS: CITIZENSPEAK IN THE 2001 BRITISH GENERAL ELECTIONS \\ KARIN WAHL- JORGENSEN
}

\begin{abstract}
This article examines citizenspeak, or the discourses available to citizens talking about politics. The paper is based on 81 interviews with voters in Bristol, England, during the 2001 British national elections. The paper finds that citizens have a narrow range of discourses to draw on. The dominant type of citizenspeak is that of immobilising discourses, expressing disenchantment with the political process. The second category is that of oppositional discourse, capturing a view of politics as the bastion of elites out to exploit the working classes.

Thirdly, the paper discusses cynical chic discourses.

The voters who engage in these discourses take

pleasure in their superior knowledge of the political process, which allows them to creatively poke fun of it. Fourth, discourses of duty emphasise the importance of voting, despite the shortcomings of representative democracy. Finally, some citizens master discourses of relevance: They speak with engagement about events touching on their own lives. And it is in these discourses that we may find hopes for the revival of citizenship.

The paper suggests that to solve the problems of disengagement, we must provide contexts in which it is acceptable to be interested in politics. This, in turn, entails broadening our definition of the political.
\end{abstract}

Karin Wahl-Jorgensen is Lecturer in School of Journalism, Media and Cultural Studies, Cardiff University, email: wahljorgensenk@cf.ac.uk. 


\section{Introduction}

The 2001 British general elections were perhaps most remarkable for the belief, widely propagated by the mass media, that the result was a foregone conclusion. The early prediction of a Labour Party landslide resulted in endless discussion of the depths of citizen cynicism and apathy. In a symptomatic June 9 leader summing up the elections, the left-wing quality paper The Guardian suggested that "the majority of voters veer between apathy and a dangerous cynicism about the way in which modern politics is conducted" (The Guardian 2001, 29).

The Guardian was not alone in issuing such declarations: With the election campaign drawing to a close, the coverage became dominated by talk of apathy and alienation, which identified fundamental problems in political institutions and deemed them culpable for a serious decline in voting. As the (Edinburgh) Evening News writer Sandy Strang put it, "there's been a growing temptation to take out one's own one-man injunction against the entire apathy-inducing democratic process and abstain" (Strang 2001, 13). On election day itself, the British local and national press published more than 400 articles on voter apathy. ${ }^{1}$ Despite the alarmist tone of these articles, talk of alienation was by no means a phenomenon unique to this election, but rather constitutes a vocabulary of political discourse that has been widely rehearsed, especially in recent years, in the UK, the US and elsewhere (e.g. Capella and Jamieson 1997; Fallows 1996; Blumler and Gurevitch 1995).

This paper looks at how citizens talk about politics, and examines the extent to which discourses of alienation circulating in the mass media map onto this particular language of politics. For the purposes of this paper, I collectively characterise the distinctive range of discourses about politics available to citizens as "citizenspeak." The categories of citizenspeak are derived from a series of interviews with voters at four polling stations in Bristol, England. The paper finds that citizens have a narrow range of discursive repertoires to draw on, and that by far the dominant form of citizenspeak — referred to as "immobilising discourses" constructs the citizens as passive, alienated, ignorant and distant from national politics. The most spontaneous form of citizenspeak occurs when citizens talk about political matters that directly touch upon their own lives. The paper suggests that if we are to battle the destructive forces of passive forms of citizenspeak, we must provide forums for positive public discourse; sites where it is acceptable to be interested in politics. This, in turn, entails broadening our understandings of the places where the political might occur.

\section{Citizenship and the Discourse of Alienation}

Our worries about citizens and their role in politics are not surprising in light of our high ideals of participation. Ever since the Enlightenment, we have viewed the rationality of citizens as the cornerstone of democracy. Thomas Jefferson, one of the earliest proponents of democracy, famously articulated the principle of selfgovernance: "I know of no safe depository of the ultimate power of the society but the people themselves" (quoted in Barber 1984, xvii). As Sinikka Sassi $(2001,120)$ puts it, the "ideal subject has been that of a vigilant citizen who must be properly informed about what is going on and be extremely active politically."

Central to our fantasies of democracy is the notion of a public sphere, facili- 
tated by media of mass communications, "a forum in which the private people, come together to from a public, read[y] themselves to compel public authority to legitimate itself before public opinion" (Habermas 1989, 25-26). As such, our ideals of citizenship celebrate discussion in public among equals (cf. Peters 1995).While theorists who are sympathetic to ideals of public deliberation have generated important insights into the problems of structuring participation and attaining equality in stratified and multicultural societies (e.g. Benhabib 1992 1996; Bohman and Rehg 1997; Fraser 1992), they have also showed us the practical inadequacy of such "thick" conceptions of citizenship: Investigations informed by such normative perspectives have shown how problems of size and scale (cf. Peters 1999) render politics increasingly distant from the lives of regular citizens.

In response to these developments, many scholars have called for us to revise our expectations of the duties of citizenship. John B. Thompson, in Media and Modernity (1995) has argued that in a time when political communication is increasingly channelled through media of mass communication, deliberation on political matters must take place in the privacy of our living rooms, not in the face-to-face public context celebrated by deliberative scholars. Thus, he envisions a passive citizen who needs political information not primarily for action, but for orientation. Similarly, in his book The Good Citizen, Michael Schudson (1998) has suggested that "if democracy requires omnicompetence and omniscience from its citizens, it is a lost cause. There must be some distribution across people and across issues of the cognitive demands of self-government" (310). He proposes the notion of "the monitorial citizen" as the saviour of democracy. Schudson's monitorial citizen engages in "environmental surveillance" for sheer survival; for information on such issues as traffic, the availability of blueberries, right-wing militias, and earthquake preparedness, but does not necessarily take an interest in purely political knowledge that affects anyone other than herself and her friends and family (310-311).

Though it is important to recognise the limited opportunities for political participation in large-scale democratic societies, a "thin" conception of citizenship such as that represented by Schudson's monitorial citizen overlooks some important dynamics of contemporary political life: First, political participation has been reconfigured in complex ways. Although it is true that many citizens now channel their enthusiasm away from politicians and parties and are, as such, not interested in conventional politics (cf. Blumler and Gurevitch 1995), it is also the case that there is a renewed interest in single-issue causes, particularly related to the environment (e.g. Buckingham 2000, 217). We also cannot ignore the mobilising ability of the anti-globalisation, anti-capitalist movement, which is the product of grassroots activism and provides a comprehensive critique of economic and political conditions (cf. Danaher and Burbach 2000). Secondly, and partly in response to some of these shifts away from usual politics, politicians have recognised the potential of popular culture to engage citizens (van Zoonen 1998, Street 1997; 2001). Bill Clinton won his first presidential campaign in 1992 playing the saxophone on the Arsenio Hall Show and fielding personal questions from teenagers on MTV, and in Britain, New Labour came to power in 1997 on a vision of a "Cool Britannia," communicated through popular media such as the Des O'Connor talk show (cf. Street 2000, p. 78). These developments signal recognition of the need to rethink the categories of citizenship and politics to reflect the changing nature of citizenship (e.g. van Zoonen 1998; 2000). 
Some scholars are critical of the courtship between politics and popular culture because they see it as trivialising public discourse (e.g. Franklin 1994; Hart 1994). They suggest that politics itself has been transformed into a performance that focuses on personality over policy, and see it as part of a larger and troubling trend through which politics has become a professionalised and managed endeavour. As essayist Joan Didion (1992) observes, in discussing American presidential campaigns:

When we talk about the process, then, we are talking increasingly, not about "the democratic process," or the general mechanism affording citizens of a state a voice in its affairs, but the reverse: A mechanism seen as so specialized that access to it is correctly limited to its own professionals, to those who manage policy and those who report on it, to those who run the polls and those who quote them, to those who ask and those who answer the questions on the Sunday shows, to the media consultants, to the columnists ... to the handful of insiders who invent, year in and year out, the narrative of public life ... What strikes one most vividly about such a campaign is precisely its remoteness from the actual life of the country (49-50).

Such observers further suggest that the media are at least in part to blame for citizen alienation, for two reasons. First, they are complicit in constructing politics as a distant spectacle restricted to politicians and media, and in which citizens can participate only as passive spectators. Secondly, and more importantly for this discussion, the media endlessly tell the story of citizen disengagement from politics, often to the exclusion of more positive representations.

This paper seeks to intervene in these debates by identifying the languages citizens have at their disposal when they speak about politics, and trying to make sense of what they are telling us about the conditions of citizenship today. Other studies of how citizens speak about politics, mostly conducted in the US (e.g. Buckingham 2000, Eliasoph 1990; 1998; Gamson 1992, Herbst 1993) conclude that even though citizens are better informed about the issues than theorists have assumed (cf. Gamson 1992, 4), they find it awkward and difficult to discuss political matters in public. Nina Eliasoph (1998), in a study of citizen activists in the US, and the difficulties they face in talking about politics, suggested that we are "avoiding politics" because we lack both places and opportunities for political discussion. She concluded that "civic etiquette made imaginative, open-minded, thoughtful conversation rare in public, frontstage settings" (230). This paper takes up the challenge to locate - against the odds - such imaginative, open-minded, and thoughtful conversation within dominant forms of citizenspeak, in the context of a national election.

\section{Method}

The discourses identified here come out of 81 brief, open-ended interviews, lasting between 5 and 15 minutes, conducted on June 7, 2001; the day of the British general election, with voters in Bristol. Bristol is a city of 450,000 in the southwest of England. It is well known as the home of the prestigious University of Bristol, and as a historically important port city. In the 2001 general elections, it was also a hotly contested area, the scene of a three-way split battle between the incumbent Labour Party Member of Parliament, and Conservative and Liberal Democrat challengers. 
While the city is relatively affluent, the city centre, where the interviews were conducted, is both economically and ethnically diverse. To reach a cross-section of the city's population, interviews were conducted at four different polling stations: 24 interviews were done at Bishopston polling station, in a middle-class, middleincome and predominantly white area. Twenty interviews took place in Easton, a multi-ethnic, low-income neighbourhood. Twenty-one voters were interviewed in Montpelier, a mixed-income and multi-ethnic neighbourhood. Finally, 16 voters in wealthy Clifton took part in the study.

The sample consisted of those people who agreed to "answer a couple of questions for a study" after being approached by the interviewer outside the polling station. Among the voters of Bishopston, Easton and Montpelier, only few people refused the request for an interview, whereas Clifton voters were more reluctant to participate, and the success rate for interview requests at that polling station was as low as 25 per cent. $^{2}$ The intention of the study was to generate a very particular sample. Thus, the people whose voices are heard in this paper are the ones most engaged and interested in the democratic process: They are people who were engaged enough to vote, and sufficiently motivated to stop and talk to the interviewer. If these motivated citizens replicate the discourses of alienation, apathy and disenchantment so widespread in mediated accounts of the elections, it might be seen as separate from the problem of voter turnout, and related to more fundamental problems of being citizens and talking about it.

In using open-ended interviews, the paper draws its conclusions based on a form of data that discourse analysts have shown to be, as David Buckingham points out in his book The Making of Citizens, "an exceptionally slippery medium. In interviews ... individual speakers will often prove to be incoherent, inconsistent, or downright contradictory" $(2000,63)$. Nevertheless, such interviews remain an invaluable method for gaining access to the ways in which people speak in public, and thus how they behave as citizens. ${ }^{3}$ They are performative modes of discourse (Kaplan 2001); they are exercises in the construction of a desirable self. While the interviewees express opinions and interpret events, they also inflect them in ways that are, consciously or not, designed as stories about themselves as actors in the social world (cf. Cameron 2001, 14-15). For the purposes of this study, the interviewee's constructions of an idealised citizenship identity are as interesting as (and inseparable from) their opinions. Indeed, the aim of the method was to gain access to a range of discourses of citizenship, and offer a "thick description" (Geertz 1973) designed to get at the significance of citizenspeak. As such, the intent here is not to make any quantitative generalisations or predictions about British voters, but to generate qualitative data in the form of discourses about politics.

Along those lines, the questions used in the interviews were designed to tap into, and generate a map of, dominant discourses of citizenship: They were questions that placed respondents in a formal, public position, similar to that of a television interview, and ones that compelled them to respond according to their expectations of how citizens ought to speak in that situation. The interviews started with the general question, "what did you think of the campaign," which was followed up with questions about the interviewee's interest in politics, as well as about their interest in the issues discussed in the different parties' campaigns, and the media coverage of the election. 
The remainder of the paper will consider these dominant discourses of citizenship articulated by Bristol voters. Citizenspeak took a number of distinct forms, each of them reflecting discourses about politics in wide circulation. Citizenspeak was generally characterised by, on the one hand, detailed knowledge of political events and personalities, but was, on the other hand, shot through with a sense of disenchantment, alienation and apathy. Each form of it represents a way of coping with what seemed to citizens the undeniable meaninglessness of national politics.

Sometimes several of these discourses appear in the statements of one interviewee. Nevertheless, they represent distinct orientations towards citizenship, and allow us to examine the range of subject positions available to citizens, and the extent to which they allow for discursive agency. Perhaps unsurprisingly, the most prominent type of citizenspeak is that of immobilising discourses; discourses expressing citizen disempowerment in the political process. These include voters complaining about the meaninglessness of politics, viewing it as an insider game, critiquing the emphasis on style over substance, and believing that politicians lie and break their promises. Because this category is by far the dominant one, it gets the most attention and space here. The second category is that of the oppositional discourses. This category shares with the immobilising discourses a sense of a profound distance between the rulers and the ruled, but is explicitly underpinned by a class analysis and powered by working-class consciousness. Thirdly, I discuss cynical chic discourses (Eliasoph 1998, 154). These discourses share with both the immobilising and oppositional discourses a sense of disenchantment with conventional politics, but the voters who engage in them take pleasure in their superior knowledge of the process, which allows them to subversively poke fun of it, and thus to participate in a limited, but meaningful way. Fourth, almost all citizens engaged in discourses of duty: Despite their expressions of disenchantment, all those interviewed emphasised the importance of voting. Finally, some citizens mastered discourses of relevance: They could speak in positive terms about politics without resorting to the "scripts" provided to them by media accounts, but only about issues touching on their own lives. And it is in these discourses, the paper argues, that we may find clues about how to revive citizenship.

\section{Immobilising Discourses: Expressing the Meaninglessness of Politics}

\section{Chasing the Middle Ground}

Many voters saw themselves as helpless pawns in a huge and incomprehensible game, and suggested that their contribution to this game would not make any difference. Like everyone interviewed for this study, they argued from a position of sophisticated knowledge of politics. The most common argument picked up on the widely rehearsed media refrain that the election was a foregone conclusion the Labour Party was going to win with a large majority. Therefore voting either for or against them made little difference to the outcome of the election.

Secondly, many respondents argued that "there just doesn't seem to be any real difference between the parties," and "they're all the same." Voters suggested that in the race for the centre, the parties were appealing too broadly, and had lost their political distinctiveness. As one young man in Bishopston put it: "They've 
just sold out to the middle ground, chasing the Tory vote, and forgotten the more Socialist policies, it's lost track of the collective will of the people, and what's good for the people as a whole, it's still old Thatcher, all about the individual, nothing's important ...I don't think that the old-left wing Socialism necessarily worked, but I think Labour now is probably more right-wing than the Tories were ten years ago."

To this voter, party politics seemed both meaningless and out of touch with a public interested in distinct policy positions. His statement was indicative of a common frustration among voters who engaged in immobilising discourses: If democracy entails the "rule of the people" and requires the consent of the governed (cf. Peters 1995, 3), the immobilising discourses contained at their core the belief that political processes have become so distanced from citizens that they stand outside these processes. This narrative takes many metaphorical forms in immobilising discourses, as citizens describe politics as a distant "insider game" run by dishonest politicians who are just in it for personal gain.

\section{Politics as Sleazy Insider Game}

The election took place in the context of a public debate about the problems associated with the professionalisation of political communications: Pundits and journalists widely denounced "designer politics" (Scammell 1995) and spin doctors. These debates gave rise to another set of immobilising discourses. Many Bristol voters picked up on their tone, and described politics as a distant game; "a game only for the players, not even for the fans" (Carey 1995, 375). As one Easton women in her 30s put it: "Politics is a game of judgmental so-and-so. I find, particularly with Labour and the Conservatives, that they just slag each other off. It doesn't seem to be about the people, it's more about putting each other down, and power."

If voters viewed politics as a game, its rules were made up by distant politicians in London, and never made transparent and comprehensible - instead, the realities of politics were obscured in a cloud of spin doctoring and media management. Thus, one young man in Bishopston argued that politics "is really based on advertising," an Easton female pensioner suggested that the campaign consisted of "a lot of backstabbing as usual," while a young Easton man suggested that "instead of slagging off other candidates, [they should be] a bit more focussed on what they're going to do and what changes they intend to make." A male Easton pensioner complained that the campaign had been too "dirty" for his liking. He gave as an example a much-discussed Labour Party poster, which featured bald Tory leader William Hague wearing a Margaret Thatcher wig, thus suggesting that he was merely a clone of the former party leader and prime minister: "[This was] certainly not the way one would expect the future leaders of this country to act. The worst example, I think, was what the Labour party done when they put the big poster with William Hague, with Thatcher. I think, to be quite honest, for a spin doctor kind of thing, that was the lowest of the low. Bearing in mind these are the future leaders of this country, they're a disgrace."

The feeling among voters that politics was an insider game inaccessible to regular citizens was strengthened by what they saw as the great distance - physically and metaphorically - between themselves and the seat of power in London. Many voters spoke of their disappointment with how little attention campaigning politicians had paid them, and related these stories to a more generalised worry about 
the success of representative democracy. As one middle-aged female voter in Montpelier put it:

Voter: We don't seem to get anyone coming around here unless there are elections going on, otherwise they leave us alone. One party is there all the time, giving us information about what they're doing, sending out newsletters, and no one else seems to bother.

Interviewer: So should they come around more?

Voter: I think they should do it all the time rather than just when they want our vote...otherwise they just leave it and carry on in their own little worlds.

Similarly, a young male Easton voter wondered out loud about the community allegiances of Members of Parliament. To him, the career politicians who move to an area only to stand for election there have no local involvement or history, and are therefore neither willing nor able to keep in mind the best interests of their constituency:

Interviewer: It's important to you that they're local?

Voter: How can they represent us as an area, if what's good for this area isn't particularly good for them? As an example I used earlier. Given the option of nuclear dumping either here or where they live, what are they gonna pick? They're gonna go, "I'm very sorry, but I'm your MP [Member of Parliament] and you're getting it." I'd like to be able to go and knock on their front door and say "Excuse me but..."

When voters suggest that politicians act primarily with their own self-interests in mind, and that these self-interests have little to do with the concerns of their constituencies, they identify a flaw in the practice of representative democratic theory that makes citizen participation pointless: They suggest that politics attracts the very people who undermine its practice. Indeed, the argument that politicians are fundamentally dishonest was perhaps the most common explanation of citizen disenchantment. For example, one Bishopston man said that "I'm now convinced that around 99 per cent of politicians are in it for their own ends," and that because of their self-interest, they will readily twist the truth. One Easton woman suggested, "They're telling us what they think we want to hear, not what we actually want to hear."

Indeed, the most widespread refrain from voters who declared themselves uninterested in politics and viewed participation in it as meaningless was that their representatives would inevitably break the promises on which they got elected. A Clifton woman in her thirties stated this point of view in terms remarkably similar to other interviewees:

Interviewer: Are you generally interested in politics?

Voter: No.

Interviewer: Why not?

Voter: Because they always promise things, and they never deliver. At the end of the day, the majority don't care at all, from what I can gather. And they all seem to be the same, every single party.

The widespread narrative of dishonest politicians was yet another metaphorical expression of the distance between representatives and the represented. Like other immobilising discourses, it pointed to the cruel joke representative democracy makes at the expense of citizens: The only way for citizens to participate is through voting, but the lack of a real choice makes this participation laughably void of meaning. 
The immobilising discourses expressed the citizens' feelings of disempowerment and resignation in relation to the political process: Though they managed to see through the politicians, they were unable to do anything about it. These discourses were immobilising because, by constantly rehearsing them, citizens reminded themselves of their place in the process as the passive, distant spectators to a spectacle they could not understand. Even the language of the immobilising discourses was frozen: It was formulaic and uncreative; for each of the statements cited here, there were a large number of other interviewees using almost-identical language. ${ }^{4}$ Out of 81 interviews, only nine, about evenly distributed between the four polling stations, were completely free of alienation.

Immobilising discourses are ultimately "anti-political" (Mulgan 1994; Kantola 2001) because, while they are critical of the process of politics, they never engage with political issues. They thus imply that it is not an act of proper citizenship to make statements of substance in public. ${ }^{5}$ The language of the immobilising discourses, in its very hopelessness, has been robbed of its ability to coordinate action and imagine constructive collective goals - it is no longer the "communicative" action, or action oriented towards a shared understanding (Habermas 1990, 67) that ought to characterise the public sphere. These voters are nevertheless using a shared language of citizenship, and the rehearsal of the discourses identified here has become a ritual of citizen participation. Paradoxically, voters behave as "good citizens" when they show an awareness of their inability to act as citizens by engaging in immobilising discourses.

\section{Oppositional Discourses: Conspiracy Theories}

A small, but vocal minority of the citizens interviewed had gone to the trouble of thinking up elaborate theories explaining the distance between the politicians and the voters. These voters were disenchanted about politics in a similar way to those rehearsing immobilising discourses. But their mood was one of anger, rather than resignation, and their explanations of the workings of politics had the sinister tint that comes with conspiracy theories. These citizens, most of whom were residents of low-income Easton, told stories that generated a sharp opposition between "the people" and "the power bloc" (cf. Fiske 1989). In their version of this age-old story, the people were helpless in the face of the overwhelming power of an elite exploiting the citizenry. ${ }^{6}$ These voters gained pleasure from their knowledge of the workings of society, but were also frustrated by their own subordinate position. One black male in his 30 s, who was voting for the first time, suggested that voting makes little difference, because the politicians themselves are at the mercy of an unseen elite: "My views of the world, of politicians, is that of puppets. They only get told what to do by very powerful people, which you and I probably don't know about. So at the end of the day, I believe that no matter who's in power, doesn't matter, certain things must be done, but they have to carry them out. They're only puppets. It doesn't matter who's in power, things are going to be the same."

An elderly white man in low-income Easton offered a similar narrative, when he suggested that the country is governed by an elite who see the working classes as their tools for attaining domination: "I think there are 20 per cent of this country who run this country, they rule the country, that's the top people. All the businessmen, etc. We're only gunfodder to these people. I was in the last war, and I can tell 
you that they don't listen to the working class, all our job is to fight for them when they get in trouble, we gotta get killed for them."

To the oppositional voters, showing up at the polling station was a form of deliberate protest, a way of voicing their dissent. Though these individuals were no more hopeful about their own possibilities for political participation than were their immobilised counterparts, they did take pride in their backgrounds as "working people." As such, they carved out a subject position more active than the voters who observed and complained about the undemocratic nature of the democratic process, only to resign themselves to it. And herein, perhaps, we may find a reason for the trouble with public discourse: The position of the citizen does not entail obvious solidarities and action plans, only voting and complaining about it.

\section{Cynical Chic Discourses}

Another group of citizens were constantly poking fun of the process, engaging in what Nina Eliasoph $(1990,1998)$ has termed a "cynical chic" discourse, or one which uses joking about politics as a way of denying personal responsibility and involvement. As such, their default response to any of the interviewer's questions would be one dripping with irony, which "can afford a safe distance from everything" (Eliasoph 1990, 474). To the cynical chic voters, "gathering information to transform into jokes was protection against being swayed by forces beyond their control. Displaying control in person was a way of making real control over these problems seem irrelevant" (Eliasoph 1998, 158). By adopting this attitude, they believe that they "have not been fooled into wasting their time on something that they cannot influence, and cannot be held responsible for whatever happens" (Eliasoph 1990, 473).

Among the Bristol voters, the cynical chic consisted of the wealthiest and most successful citizens, who projected an image of themselves as above the petty details of politics, yet comprehensively informed and aware. Though low-income Easton harboured some of the most articulate and resistant voters, it represented none of the practitioners of the "cynical chic" discourses: They all resided in firmly middle - or upper-middle class neighbourhoods. One young businesswoman in Bishopston, who took off after the interview in a Jaguar, revealed her disenchantment in the following terms:

Interviewer: Do you think the process is interesting?

Voter: No, it's a waste of taxpayers' money.

Interviewer: Even though you disillusioned, you still come out to vote?

Voter: Yes, you do have to vote...But I don't think it makes much of a difference. There was a Scottish Party, the Raving Mad Lunatics Party, who dress up like rainbows and crocodiles, and I always said that everyone should vote for them, because they're the only politicians who ever thought about something in their life.

Likewise, an expensively dressed, middle-aged couple in Clifton, whose interview was interrupted many times by friends and acquaintances, shared a joke that communicated their own feelings of distance from the political process:

Interviewer: What steps should be taken to improve the way politics is run?

Female voter: I thought the ballot box was lovely ... it's not my democratic right to have a battered old black one. 
Male voter: The ballot box...I think the new zip-up ballot box is lovely, that's an improvement, the only improvement to democracy we've had this time. There are a few other things that should have been zipped up, like Lord [Jeffrey] Archer's flies, they should have been kept zipped.

Interviewer: So what do you think could be improved in politics?

Male voter: Well, there seems to be a lack of engagement and enthusiasm and passion and fire...

Interviewer: How would you bring that back into politics?

Male voter: Emigrate.

The citizens who engaged in these cynical chic discourses revelled in their own wit and knowledge, and played out an enjoyable drama of disengagement from politics, drawing on the ironic and joking forms prevalent in popular culture. They were irreverent in their insistence on turning the cruel joke of representative democracy against itself. They were also conversant with, and able to subvert, the clichéd language of politics that the immobilised voters so abundantly spoke: They talked about their "democratic right," and "improvement to democracy," poked fun of the preoccupation with voters" "lack of engagement and enthusiasm." Their contribution to citizenspeak was creative and challenging. They offered sophisticated critiques that they might not have been able to get across in any other language. They showed that groups of citizens are interested in politics, well-informed and reflective - if mostly about its shortcomings. On the basis of these discourses, it seems that politics is enjoyable when people can have fun talking about it. As such, citizenspeak challenges the dry seriousness that might be one reason why so many citizens find conventional politics boring and irrelevant.

Nevertheless, underneath the joking rested the same tacit acknowledgement of the meaninglessness of politics, and the moral inadequacy of politicians that scaffolded the immobilising discourses. We should thus not forget that the cynical chic discourses, even if they show more engagement and creative thinking than the immobilising discourses, do not fundamentally challenge the status quo. As Eliasoph $(1990,475)$ reminds us:

A key aspect of the cynical chic stance is that, while it gives the appearance and feeling of control, and in part may be an accurate assessment of powerlessness and ignorance, it leaves the government free to act without any popular restraint whatsoever; people can have the appearance of control without risking actually trying to take control.

As such, the creativity of cynical chic offers participation and communicative power in a limited context. Outside of this context, the corrupted representatives ruled undisturbed.

\section{Discourses of Duty: Why Should We Vote?}

Despite the widespread disengagement from national politics, all respondents stressed the importance of voting. In a political environment where most interviewees felt they had very little influence on specific decision-making, voting was seen as the only form of "real" citizen participation. Also, in the vast majority of interviews, respondents characterised voting not merely as a form of political participation, but a much-needed tool for expressing dissent. A middle-aged male in Bishopston expressed his position as follows: 
Voter: I do think that not to vote is a terrible waste. I understand apathy, but I've never found myself to be so apathetic I wouldn't vote at all.

Interviewer: Why is it a waste?

Voter: Because it's a democracy and I think people should exercise their right, I think apathy is the worst enemy. I think once people cease caring about the issues ... I'm concerned about social justice, and I think unless we participate in the debate, social justice goes out the window. I think just the sharks and the strongboys and the people with the biggest voices will take over, cynical people will take over...

This voter's response was symptomatic of the fact that in speaking about voting as a "civic" duty, voters found a space for expressing a depth of positive emotions about politics, opening the gates for the kinds of earnest and explicitly political sentiments barred from immobilising, oppositional and cynical chic discourses. Like this man, most interviewees, even if they generally spoke with little hope about politics, passionately invoked the "democratic right" that the cynical chic respondents so successfully lampooned. Nevertheless, the respondents almost unfailingly pointed to the limitations of voting. As one elderly white male in lowincome Easton poignantly put it: "Voting is the only way I can do anything, the only way I can register a protest. If you're a wealthy man, you can go out and hire a campaign. Like the Referendum Party ... This billionaire spent 20 million pounds having leaflets printed, he could afford it. Now if I was a millionaire, I could go into an established party or start my own party. But if you're a poor man, you can only register your complaint...Your rights are right here, in that ballot box. Don't bellyache after if you haven't done anything about it in the first place."

This sentiment was echoed by many other voters, to whom voting in the elections constituted a tiny, but significant rebellion against forces much larger than themselves. In the discourses of duty, there was a common ground of minimal participation that allowed voters a brief retreat from the meaninglessness of politics. One young man in Bishopston put it as follows: "As far as democracy, it's only a democracy when we're voting, and for the next four years you don't have anything. I mean you're not voting for a particular policy, they're [sic] voting for a catch-all party. I think that's what causes all that apathy, because you can't vote for a particular issue, you can only vote for a party every four years."

This critique points to a problem in the theory of representative democracy that has haunted thinkers for centuries: It does not provide adequate mechanisms for citizen participation in political decision-making. Voters like this one articulated Rousseau's $(1968,141)$ belief that the "English people believes itself to be free; it is gravely mistaken; it is free only during the election of Members of Parliament; as soon as the Members are elected, the people is enslaved; it is nothing." Indeed, many of the voters who advanced "discourses of duty" suggested revamping representative democracy by introducing proportional representation and relying more on referenda and other forms of direct democracy.

The discourses of duty, even if they betray the core belief in the meaninglessness of national politics as it is currently conducted, show that citizens are willing and able to be engaged, and that what is missing are the conditions for such engagement. Periodic elections, even if they are a fixed feature of contemporary democratic practice (e.g. Held 1987, 260) must be supplemented by other measures enabling citizens to think and act politically. 


\section{Discourses of Relevance: The Politics of Everyday Life}

Only few citizens spoke in words completely free of political disenchantment and alienation. Though a relatively large number of respondents suggested that they were "reasonably interested in politics" and followed news about the campaign, most found grounds for distrusting and disliking politicians, and paying little attention to processes of national politics. An exception was one young Asian male, who was a first-time voter, and thought that "democracy is wicked":

Voter: I found it empowering to just be able to make a decision for myself, and to choose to look into what I felt were the best options for myself, and then acting.

Interviewer: So you see this election as empowering for you then?

Voter: To an extent. It's nice to be able to exercise your democratic rights, and this being the first time I've been able to do that, it makes me feel like I'm doing something sort of fairly worthwhile. Obviously, that's quite an odd thing to say because of all the controversy around elections and what they're worth, but I feel quite good about it.

This citizen, and other less vocal, but equally happy voters showed their perception of politics as an act of making a contribution to collective decision-making, and understanding how individuals fit into and can play a role in society. This turned out to be the key to finding contexts in which regular citizens spoke positively about politics. To most people, as we have seen, national politics offers few opportunities for substantive involvement. Indeed, as Gamson (1992) argues, given the distance and abstraction of national politics, it is remarkable that any citizens take an interest (68), let alone that some also find the time and courage for engaging in political action (Gans 1988, cited in Gamson 1992, 62). Kevin Barnhurst, in studying young people's attitudes to political news suggests that much "of what passes for political news on television and in the papers - because it simply doesn't have meaning within the localities where they live - never reaches these young citizens. The news floats past them, unanchored. The reports might just as well be circulating in another dimension" (Barnhurst 1998, 215-216).

The same was true of Bristol voters, who mostly found little reason to celebrate the election spectacle. However, voters were much more likely to express enthusiasm and speak without resorting to immobilising clichés when they talked around the edges of conventional politics. What made the difference to the voters was what Gamson $(1992,163)$ calls "proximity," or "the degree to which an issue has direct and immediate consequences for one's personal life," and what others have referred to as "relevance" (e.g. Buckingham 2000, 221; Wahl-Jorgensen 2001): Whenever they saw a connection between the abstractions of national politics - or macropolitics - and their own experience — or micropolitics - they were much more likely to talk at length, offer their own opinions, and tell stories that illustrated unique insights (cf. also Ettema and Glasser 1998, 197-200). As one female Easton voter put it, national politics does not hold enough relevance to regular citizens, who must be engaged at the local level:

Interviewer: Would you say you're most interested in local or national politics?

Voter: I think you've got to start at local level, start at the grass roots. I think local politics is more relevant.

Interviewer: Do you feel national politics is too removed from your own experience?

Voter: Definitely. It's a bit depressing that there aren't many people coming. They've been told 
they're alienated. They've been conditioned into believing that, and that's why they won't turn up, it would be odd if they did.

To this voter and others, the alienation that was the talk of the day and shaped the immobilising discourses is the result of poor political socialisation and media coverage that doesn't show the relevance of politics to regular citizens. Another citizen, a middle-aged Montpelier man, identified his interest in local politics on the basis of its impact on his everyday life:

Voter: I am interested in politics, but largely about how it impinges upon me and my family, but also perhaps a bit more in local politics

Interviewer: So local politics is more important to you?

Voter: It affects my children's school directly...My son's school has had a budget cut this year. So we've got a Labour Council, we've got a Labour MP, and one of the key things in this election for Tony Blair is "education, education, education," and it's just not how...The first thing he did was to put the thousands of pounds in tuition fees for students, and then my son's secondary school budget has been cut significantly, so what's going on? ... National politics are relevant, but I think the difference is, it's much less tangible how it affects you. Obviously if someone comes in and puts some money in the income tax, that's directly ... but it's the local politics that affects me directly, in a way I can really feel, that really has an effect.

These voters, well informed, argumentative, and active in their approach to politics, distinguished themselves by actively talking about their position on substantive political issues. Along with those speaking the discourse of duty, they offered constructive and positive proposals for how to improve the political process.

In their ability to speak freely and uniquely about their own positions, they show us that when politics can be redefined as relevant to the lives of citizens, it is neither embarrassing, depressing nor difficult to speak about it. This is not to set the stage for a celebration of the power of local politics to transform citizenship: As election statistics show, local elections get much lower turnout than national ones, and citizens are much less interested in them (e.g. Doppelt and Shearer 1999, 5). But we can learn something about how to successfully rethink political engagement from listening to citizens speaking in an unscripted way about the issues that matter to them. As we have seen, these citizens are not unique in showing an engagement with politics. But unlike the other forms of citizenspeak discussed here, they showcase citizens who see some point to conventional politics. In the next and final section, I will seek to understand why this is the case, and how we can learn from the discourses of relevance to reform conventional politics.

\section{Conclusion: Towards a New Conception of Politics}

This article has examined citizenspeak, or the range of discourses citizens have available to them when speaking up in public. We have seen that when citizens are consistently cast by mass media and politicians as alienated and uninterested in politics, it is an uphill struggle for them to find any other subject position. Despite their differences, the five discourses described here share some features that bear witness to fundamental problems of contemporary citizenship: They all reflect an underlying belief that national politics has little to do with the everyday lives of citizens. In each their own way, these discourses recognise and critique problems of representative democracy, suggesting that it is flawed in theory because voting once every four years is not an adequate exercise of citizenship (discourses of duty) and flawed in practice for a multitude of reasons (all discourses). 
While the immobilising discourses construct acquiescent, but alienated subjects, the oppositional discourses foster class-based resistance, the cynical chic discourses bring about witty joking, the discourses of duty accept limited citizenship, and the discourses of relevance look for alternative loci for politics. Of all the discourses, the latter is the only one that offers a direct engagement with the issues of conventional politics. As such, analysing the way it works is the key to rethinking politics because it might show us how governments and parties can adapt to the changing dynamics of citizenship.

To move towards solving the problems of citizen disengagement from conventional politics, we need to identify a productive way to anchor the political energies and knowledge evident in all the discourses reported here. Keeping in mind the importance of proximity, I suggest that we draw on the implications of discourses of relevance to rethink our understanding of the political. Eliasoph (2000) has offered an important starting point for such discussions when she suggested that we need to pay attention to "everyday citizenship." She argues that "cultivating a keen attentiveness to everyday life, local landscapes, particular individuals, specific drill bits and holes, is an important part of everyday citizenship, without this specificity, citizenship risks becoming cruelly abstract and impersonal" (77).

Eliasoph is thus suggesting that if we understand the political more broadly, in terms of the everyday experiences that link us up to shared problems, we can create sustainable spaces for the exercise of citizenship. A broader definition of the political encourages us to look for emerging practices of citizenship whenever and wherever people get together and try to connect with and understand others - in homes, where mothers tell their daughters about their trips to the doctor, in newspaper letters to the editor about the closing of local businesses, and on trains, where people talk to strangers about delays and their causes. It means we should understand that politics is not the preserve of national elites. We should recognise the authority of citizens to authentically and openly talk about politics in public. And we should be protective and nurturing of any context in which citizens constructively mobilise to talk about politics - whether it be in pensioners' clubs, teacherparent associations, or anti-globalisation protests. Sassi (2001) has suggested that if we cast the net more widely when looking for political discourses, we can draw on already-existing institutions central to people's lives:

the sources of opinion formation can be found in sociality and in the sphere of culture... Sociality is the essence of human life, which we do not need to invent or reinvent because it has existed and it will exist, even when all political institutions have collapsed. Instead of starting with the formal political organs we can begin to observe local life as such and try to discern action that is collective by nature, that is, transcends the individual sphere and emerges as something public (122).

In this view, the political happens in moments when solidarity with other people links up with the questions of justice to which we must attend - when the personal and the particular is linked up to the shared and the general. Such a broad understanding of the political can help us to empower citizens who live their everyday lives continually, but often fleetingly, touching upon and engaging with the larger contexts that surround them. It can challenge media institutions and political parties alike to revise the top-down agenda-setting practices that fill our news 
programmes and papers with stories about elites, and compel those in power to take seriously the political potential of citizenship.

Politicians' engagement with popular media forms, such as television talk shows, goes some way towards addressing the disconnect between citizens and those who represent them (cf. Zoonen 1998, 196-197). But on its own, it is not sufficient: while it helps to make accessible the ideas of the politicians, there remains a strong sense among the citizens interviewed here that politicians have no access to their ideas about what politics should be about, and that they do not care to make an effort to change that state of affairs. Dealing with this problem would entail a much more fundamental rethink of the priorities of political parties. Though polling, focus groups, public forums and walkabouts are routine elements of political campaigning, these points of contact with voters are not used to centrally shape the agenda of parties or to get at how citizens think of politics. Instead, they are used to test the marketing of already-existing issues. If the methods behind the "packaging of politics" were used to systematically rethink what politics should be about, along the lines suggested here, we might mobilise some of the citizens who now turn away from democracy.

\section{Notes:}

1. According to a Lexis-Nexis search using the terms "voter" and "apathy," which yielded 430 stories on June 7 alone, only a few of which did not directly deal with the same day's national election.

2. This discrepancy in participation might have been caused by the time of day during which the interviews were conducted: Whereas Bishopston, Easton and Montpelier interviews were conducted during the morning, day, and late afternoon, the Clifton interviews took place at night, where people might have had more familial and social obligations.

3. Eliasoph (1990) provides a detailed and insightful discussion of the use of such methodology.

4. It is also interesting to note that the immobilising discourses, here articulated by the most motivated of voters, closely mirrored the reasoning of US. non-voters interviewed by the research team of Jack Doppelt and Ellen Shearer (1999). On the whole, the "concerned citizen" who expresses informed and serious views on the issues to other students of political discourse (cf. Eliasoph 1990, 483-486; Gamson 1994) was almost entirely absent from this study: The invitation to speak about their opinion in the context of the campaign elicited responses about process, procedure and strategy instead of substance.

5. See also Hallin $(1994,19)$ for a helpful discussion of how the emphasis on "process" or "technical and strategic questions" in political discourse effectively does away with communicative action.

6. One variation on this tale was offered by a Tory voter in Montpelier, who critiqued what she saw as the hegemonic conspiracy of left-wing media organisations: Among other things, she suggested that a "lot of the media is owned by left-wing organisations, which is one of the reasons why Labour got in last time, and I think it's atrocious."

\section{References:}

Barber, Benjamin R. 1984. Strong Democracy: Participatory Politics for a New Age. Berkeley, CA: University of California Press.

Barnhurst, Kevin G. 1998. Politics in the Fine Meshes: Young Citizens, Power and Media. Media, Culture and Society 20, 201-218.

Benhabib, Seyla. 1992. Models of Public Space: Hannah Arendt, the Liberal Tradition, and Jürgen Habermas. In C. Calhoun (ed.), Habermas and the Public Sphere, 73-99. Cambridge, Mass.: MIT Press. 
Benhabib, Seyla. 1996. Toward a Deliberative Model of Democratic Legitimacy. In S. Benhabib (ed.), Democracy and Difference: Contesting the Boundaries of the Political, 67-95. Princeton, N. J.: Princeton University Press.

Blumler, Jay and Michael Gurevitch. 1995. The Crisis of Public Communication. London: Routledge.

Bohman, James and William Rehg, eds. 1997. Deliberative Democracy: Essays on Reason and Politics. Cambridge, MA: MIT Press.

Buckingham, David. 2000. The Making of Citizens: Young People, News and Politics. London: Sage.

Cameron, Deborah. 2001. Working With Spoken Discourse. London: Sage.

Capella, Joseph and Kathleen Hall Jamieson. 1997. Spiral of Cynicism: The Press and the Public Good. New York: Oxford University Press.

Carey, James. 1995. The Press, Public Opinion, and Public Discourse. In T. L. Glasser and C. T. Salmon (eds.), Public Opinion and the Communication of Consent, 373-402. New York: Guilford Press.

Danaher, Kevin and Roger Burbach, eds. 2000. Globalize This! Monroe, Maine: Common Courage Press.

Didion, Joan. 1992. After Henry. New York: Simon \& Schuster.

Doppelt, Jack C. and Ellen Shearer. 1999. Nonvoters: America's No-Shows. Thousand Oaks, CA: Sage.

Eliasoph, Nina. 1990. Political Culture and the Presentation of a Political Self: A Study of the Public Sphere in the Spirit of Erving Goffman. Theory and Society 19, 465-494.

Eliasoph, Nina. 1998. Avoiding Politics: How Americans Produce Apathy in Everyday Life. New York: Cambridge University Press.

Eliasoph, Nina. 2000. Where Can Americans Talk Politics: Civil Society, Intimacy, and the Case for Deep Citizenship. Communication Review 4, 65-94.

Ettema, James S. and Theodore L. Glasser. 1998. Custodians of Conscience. New York: Columbia University Press.

Fallows, James M. 1996. Breaking the News. New York: Pantheon Books.

Fiske, John. 1989. Understanding Popular Culture. London: Routledge.

Franklin, Bob. 1994. Packaging Politics: Political Communications in Britain's Media Democracy. London: Edward Arnold.

Fraser, Nancy. 1992. Rethinking the Public Sphere: A Contribution to the Critique of Actually Existing Democracy. In C. Calhoun (ed.), Habermas and the Public Sphere, 109-142. Cambridge, Mass.: MIT Press.

Gamson, William A. 1992. Talking Politics. Cambridge: Cambridge University Press.

Gans, Herbert. 1979. Deciding What's News. New York: Pantheon.

Geertz, Clifford. 1973. The Interpretation of Cultures. New York: Basic Books.

Guardian. 2001. Champagne and Ashes. Celebrate Victory: Be Alarmed by Apathy. The Guardian, June 9, 29.

Habermas, Jürgen. 1989. The Structural Transformation of the Public Sphere. Cambridge, MA: MIT Press.

Habermas, Jürgen. 1995. Moral Consciousness and Communicative Action. Cambridge, MA: MIT Press.

Hallin, Daniel C. 1994. We Keep America on Top of the World: Television Journalism and the Public Sphere. New York: Routledge.

Hart, Roderick. 1994. Seducing America: How Television Charms the Modern Voter. New York: Oxford University Press.

Held, David. 1987. Models of Democracy. Stanford, CA: Stanford University Press.

Herbst, Susan. 1993. The Meaning of Public Opinion: Citizens' Constructions of Political Reality. Media, Culture and Society 15, 437-454.

Kantola, Anu. 2001. Leaving Public Places: Antipolitical and Antipublic Forces of the Transnational Economy. Javnost-The Public 8, 1, 59-74. 
Kaplan, Carla. 2001. Talk to Me: Talk Ethics and Erotics. In S. I. Salamensky (ed.), Talk Talk Talk:

The Cultural Life of Everyday Conversation, 63-76. London: Routledge.

Mulgan, Geoff J. 1994. Politics in an Anti-Political Age. Cambridge: Polity Press.

Peters, John D. 1995. Historical Tensions in the Concept of Public Opinion. In T. L. Glasser and C. T. Salmon (eds.), Public Opinion and the Communication of Consent, 3-32. New York: Guilford.

Peters, John D. 1999. Public Journalism and Democratic Theory: Four Challenges. In T. L. Glasser (ed). The Idea of Public Journalism, 99-117. New York: Guilford Press.

Rousseau, Jean-Jacques. 1968. The Social Contract and Discourse on the Origin of Inequality. New York: Washington Square Press.

Sassi, Sinikka. 2001. Public Opinion as Local Opinion. In S. Splichal (ed.), Public Opinion \& Democracy, 103-122. Creskill, NJ: Hampton Press.

Scammell, Margaret. 1995. Designer Politics. London: Macmillan.

Schudson, Michael. 1998. The Good Citizen: A History of American Civic Life. New York: Free Press.

Strang, Sandy. 2001. Apathy in the UK Wins Dull Election. Evening News, June 7, 13.

Street, John. 1997. Politics \& Popular Culture. London: Polity Press.

Street, John. 2001. The Transformation of Political Modernity. In B. Axford and R. Huggins (eds.), New Media and Politics, 210-224. London: Sage.

Thompson, John B. 1995. The Media and Modernity: A Social Theory of the Media. Stanford, CA: Stanford University Press.

Wahl-Jorgensen, Karin. 2001. Letters to the Editor as a Forum for Public Deliberation: Modes of Publicity and Democratic Debate. Critical Studies in Media Communication 18, 3, 303-320.

Zoonen, Liesbet van. 1998. A Day at the Zoo: Political Communication, Pigs and Popular Culture. Media, Culture and Society 20, 183-200.

Zoonen, Liesbet van. 2000. Popular Culture as Political Communication. Javnost-The Public 7, 1, 5-18. 